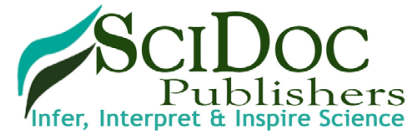

International Journal of Food Science, Nutrition and Dietetics (IJFS)

ISSN:2326-3350

\title{
Shelf Life Study and Quality Attributes of Cocoyam Chips
}

Research Article

Adebayo-Oyetoro Abiodun $\mathrm{O}^{1 *}$, Edeh Charles $\mathrm{K}^{1}$, Adeyeye Samuel, A.O ${ }^{2}$, Ogundipe Oladeinde $\mathrm{O}^{1}$, Akinwande Femi $\mathrm{F}^{1}$, Ogundipe, Flora $\mathrm{O}^{3}$, Bamidele Florence $\mathrm{A}^{3}$

${ }^{1}$ Department of Food Technology, Yaba college of Technology, Yaba, Lagos State, Nigeria.

${ }^{2}$ Department for Management of Science and Technology Development, Ton Duc Thang University, Vietnam.

${ }^{3}$ Department of Biological Science, Yaba college of Technology, Yaba, Lagos State, Nigeria.

\section{Abstract}

The study was carried out to determine changes in the quality indices (levels of peroxides values, acid values, $\mathrm{pH}$ and colour) of cocoyam chips and microbiological safety (bacterial, yeast and mould counts) of cocoyam chips as influenced by temperature during storage period of fried cocoyam chips. Cocoyam tubers were processed into chips of $3 \mathrm{~mm}$ thickness; the slices were then fried at a frying temperature of $170^{\circ} \mathrm{C}$ in a shallow pot for 7 minutes and was packaged in polyethylene bags and stored under room and refrigerator temperature. The results showed that there was significant difference $(\mathrm{p} \leq 0.05)$ between quality indices, microbiological safety and storage temperature and packaging materials. From week $0-5$, peroxide values of samples stored under refrigeration temperature were found to be low, ranged from $3.39-11.58 \mathrm{meq}^{-1}$, while the samples stored in the room temperature were found to be higher $3.81-12.87 \mathrm{meq} \mathrm{kg}{ }^{-1}$. Acid values were also found to be low in the samples stored in the refrigerator, ranged from $5.79-163.34 \mathrm{mg} / \mathrm{g}$ and the samples that were stored in the room temperature ranged from $9.94-24.05 \mathrm{mg} / \mathrm{g}$. The samples stored under refrigeration temperature had low bacterial counts ranged from $5.0 \times 10^{1}-6.2 \times 10^{1} \mathrm{cfu} / \mathrm{ml}$ while samples stored in the room temperature had higher bacterial counts, ranged from $9.0 \times 101-74 \times 101 \mathrm{cfu} / \mathrm{ml}$. Yeast and mould counts in samples stored under refrigeration temperature ranged from $4.0 \times 10^{1}-32 \times 10 \mathrm{cfu} / \mathrm{ml}$ while the samples that were stored in room temperature had higher counts, ranged from $3.0 \times 10$ $-38 \times 10 \mathrm{cfu} / \mathrm{ml}$. pH ranged between $6.88-7.02$ for both samples during storage period. The results showed that storage temperature and properly sealed packaging material has effect on the above parameters that were determined. There were also colour changes during the storage period.

Keywords: Cocoyam Deep Fat Frying; Shelf Life Study; Cocoyam Chips.

\section{Introduction}

Cocoyam is a staple root crop that belongs to the Araceae family. The plant grows best in well drained light texture soils but can still tolerate heavy texture soil with $\mathrm{pH}$ from 5.5 to 6.5 [33]. It is an herbaceous monocotyledon plant of $1 \mathrm{~m}$ height. The above ground stem consists of heart shaped leaves supported by soiled and long erect petioles. The underground corm is a compact structure filled with nutrients [28].

It is an important crop in tropical and subtropical areas because it provides carbohydrates, proteins, fats and vitamins. It is highly nutritious with a considerable amount of carbohydrate $(88.04 \%)$, ash $(3.20 \%)$, crude protein $(5.19 \%)$ crude fibre $(2.86 \%)$ and $0.40 \%$ ether extract [2]. It has more crude protein and its starch is highly digestible because of the small size of its granules. It has a reasonable amount of calcium, phosphorus and vitamins A and B. Cocoyam can be processed in different forms; boiled, roasted or processed to fried slices (chips) which are available in the market [26].

Deep-fat frying is a process in which rapid moisture loss occurs and crisps acquire minimal moisture content [11]. Deep oil frying is one of the most popular methods of preparation of food due to the fact that it is easy to use, fast and relatively cheap and results in palatable foods preferred by many consumers. The oil

\footnotetext{
*Corresponding Author:

Adebayo-Oyetoro Abiodun Omowonuola,

Department of Food Technology, Yaba college of Technology, Yaba, Lagos State, Nigeria.

Tel: +2348055300970

E-mail: abiodun.oyetoro@yabatech.edu.ng/wonunext@gmail.com

Received: August 25, 2017

Accepted: November 20, 2017
}

Published: November 23, 2017

Citation: Adebayo-Oyetoro Abiodun O, Edeh Charles K, Adeyeye Samuel A.O, Ogundipe Oladeinde O, Akinwande Femi F, Ogundipe, Flora O, Bamidele Florence A. Shelf Life Study and Quality Attributes of Cocoyam Chips. Int J Food Sci Nutr Diet. 2017;6(4):366-371. doi: http://dx.doi.org/10.19070/2326-3350-1700065

Copyright: Adebayo-Oyetoro Abiodun $\mathbf{O}^{\circ}$ 2017. This is an open-access article distributed under the terms of the Creative Commons Attribution License, which permits unrestricted use, distribution and reproduction in any medium, provided the original author and source are credited. 
does not only function as a medium for heat transfer from the heating source to the food, but also serve as enhancer of flavour, responsible for the typical smell and taste of the fried products [23]. However, due to the high temperature used in frying $\left(170^{\circ} \mathrm{C}\right)$ undesirable off-flavours occur if deteriorated oil is used or if the oil is used over a long period of time. Among the reaction that occur during frying and storage are oxidation and hydrolysis [17].

Deep-fat frying is an established process of food preparation and a process of cooking foods by immersing them in edible oils and fats at elevated temperatures to induce fast dehydration. It is a simultaneous heat and mass transfer process where moisture leaves the food in the form of vapour bubbles, while oil is absorbed simultaneously [16].

The shelf life of fried snack foods depends, to a large extent, on the quality of the frying medium because significant quantities of the frying medium are absorbed by the food. Potato chips, for example, increase in fat content from less than $1 \%$ to over $30 \%$ during frying [21].

Hawrysh et al., (1996) [14] tested the stability of potato chips which had been fried in four different oils: canola, partially hydrogenated canola, soybean and cottonseed, under two storage temperatures in the absence of light: accelerated $\left(60^{\circ} \mathrm{C}\right)$ for 12 days, and ambient $\left(23^{\circ} \mathrm{C}\right)$ for 18 weeks. During accelerated storage, potato chip odour/flavour and off-odour were not affected by oil type. However, after 18 weeks at room temperature, chips which had been fried in canola oil had higher typical potato chip odour/ flavour and lower off-odour/flavour than chips fried in the other oils. In contrast, Hawrysh et al., (1995) [15] reported higher characteristic odour and lower off-flavour, rancid and painty odours in tortilla chips fried in LLCO, corn oil and partially hydrogenated canola and soybean oils than RCO after 16 days of storage at $60^{\circ} \mathrm{C}$. No differences were found among oil types for chips stored at room temperature for 24 weeks.

Warner et al., (1994) [37] also reported potato chips fried in RCO had the lowest flavour quality scores after four months of storage at $25^{\circ} \mathrm{C}$ compared to chips fried in hydrogenated, low linolenic and high oleic canola oils. Similarly, RCO chips had significantly higher amounts of total volatiles than the chips fried in the other three oils, and high oleic canola oil (HOCO) and LLCO chips had lower amounts of total volatiles than hydrogenated canola oil. Petukhov et al., (1999) [32] found chips fried in RCO had greater rates of accumulation of peroxides, free fatty acid, conjugated dienoic acids and polar compounds and developed higher levels of total volatiles over the 16 days of storage at $60^{\circ} \mathrm{C}$ than chips fried in LLCO, HOCO and hydrogenated canola oil. Chips fried in all oils except hydrogenated canola oil had similar rates of development in painty odour as storage time increased. Chips fried in hydrogenated canola oil exhibited an intense stale/musty odour by the end of 16 days of storage.

Chill storage of fried chips and foods using different oils is common; however, the effect of chill storage on the quality indices of the chips with reference to its levels of peroxides values, acid values, $\mathrm{pH}$ and colour and microbiological safety (bacterial, yeast and mould counts) of cocoyam chips is not well known. Therefore, the study was carried out to determine changes in the quality indices (levels of peroxides values, acid values, $\mathrm{pH}$ and colour) of cocoyam chips and microbiological safety (bacterial, yeast and mould counts) of cocoyam chips as influenced by temperature during storage period of fried cocoyam chips.

\section{Materials and Method}

\section{Processing of Cocoyam Chips}

Cocoyam (Colocasia esculenta) chips (60 samples) that were used for this work were purchased from local processors in Ajilete market, Abeokuta, Nigeria while the cocoyam chips (20 samples) that were used as control were produced in the food processing laboratory. Fresh red cocoyam (Colocasia esculenta) corms were purchased from Yaba market in Lagos, South West Nigeria. Tubers weighing between 1.0 and $1.50 \mathrm{~kg}$ were selected from the lots, washed, graded into weight classes. Vegetable oil (Kings Brand), table salt (Dangote brand) was purchased at the same market.

\section{Methods of Preparation of Control Sample}

The cocoyam tubers were used for this study. These were peeled and sliced using knife to a uniform thickness of $3 \mathrm{~mm}$, the slices were washed in running tap water to remove surface starch, soaked in salt solution for 15 minutes followed by the removal of slices in colander and fried in a shallow pot containing about 3 litres of vegetable oil (kings brand) at a temperature of $170^{\circ} \mathrm{C}$ for 7 minutes. The fried slices were removed and excess oil drained off for 1 minute, cooled and packaged [36].

\section{Storage of Cocoyam Chips (0-5 weeks)}

The purchased market samples and control samples that were processed in the food processing laboratory were stored under room and refrigeration temperatures. As a measure of shelf life, the cocoyam chips were analyzed for peroxide value, acid value, yeast and mould count, bacterial count, $\mathrm{pH}$ and colour immediately and thereafter at every week interval during storage for 5 weeks.

\section{Determination of Peroxide Value}

Peroxide value was determined according to the standard AOAC (2000) with two duplicate per analysis.

\section{Determination of Acid Value}

Acid values were determined according to the standard AOAC (2000) with two duplicate per analysis.

\section{Determination of $\mathrm{pH}$}

The $\mathrm{pH}$ was measured by $10 \%$ (w/vol) suspension of each sample in distilled water; this was achieved by dissolving $10 \mathrm{~g}$ of the sample in $100 \mathrm{ml}$ of distilled water. Each was mixed thoroughly and filtered. The $\mathrm{pH}$ of the filtrate was measured using $\mathrm{pH}$ meter (Combo pH and EC, model H19812, Hanna England).

\section{Determination of Colour}

The colour of the fried cocoyam chips was measured in the $\mathrm{L}^{*} \mathrm{a} \mathrm{b}^{*}$ mode of CIE (Angle 10, illuminant D65) using a Hunt- 
er lab (DP 9000, Hunter Association laboratory, Reston, USA). $\mathrm{L}^{*} \mathrm{a} * \mathrm{~b} *$ indicate lightness, redness and yellowness respectively.

Bacterial count, yeast and mould count was determined by method of Okolie (2012).

\section{Statistical Analysis}

Data were subjected to one-way analysis of variance (ANOVA), using Prism 6 for windows, version 6.01. The LSD/Tukey studentised range test was used to compare differences between means when the ANOVA result was significant $(p<0.05)$.

\section{Results and Discussion}

\section{Peroxide Value}

Table 1 showed that peroxide value increased as the storage weeks progressed which indicate that the rate of rancidity increases with respect to the storage time which causes off flavour and odour. The trend was in agreement with the observation reported by Amir et al., (2005) [6].

No significant, $(p>0.05)$ difference was found between the sam- ple that was stored under refrigeration temperature in week 0 . However, between 1-5 weeks, some significant $\mathrm{p}<0.05$ differences between the sample that was stored under room temperature. Peroxide value was noted to have increased after week 1 but in both storage conditions but was more evidence in the sample that was stored in the room temperature [10].

The peroxide value is a measure of oxidative rancidity, the lower the peroxide value the better is the oil quality [6]. Loss of acceptability of fried cocoyam chips during storage was primarily due oxidative rancidity. Storage of chips at higher temperature increased the levels of peroxides, indicating the significant role of heat in oil hydrolysis and oxidation. It therefore means that chips stored in the room temperature will develop rancidity faster compared to those stored in the refrigeration temperature. Also, increase in peroxide has been found to be a good predictor of fat deterioration [38].

The sample that stored at room temperature have more rancidity because of thermal effect and enzyme kinetics which could also be as a result of build-up of free radicals which reacted with oil by exposure to light rays [16], thus causing fat oxidation and rapid deterioration in chips flavour. The rancidity can also be attributed to the composition and nature of fatty acid in the oils

Table 1. Results for Peroxide Value.

\begin{tabular}{|c|c|c|c|c|c|c|}
\hline Sample & Week 0 & Week 1 & Week 2 & Week 3 & Week 4 & Week 5 \\
\hline & $\begin{array}{c}\text { Peroxide value } \\
\text { meq kg-1 }\end{array}$ & $\begin{array}{l}\text { Peroxide value } \\
\text { meq kg-1 }\end{array}$ & $\begin{array}{l}\text { Peroxide value } \\
\text { meq kg-1 }\end{array}$ & $\begin{array}{l}\text { Peroxide value } \\
\text { meq kg }\end{array}$ & $\begin{array}{c}\text { Peroxide value } \\
\text { meq kg-1 }\end{array}$ & $\begin{array}{l}\text { Peroxide value } \\
\text { meq kg }\end{array}$ \\
\hline $\mathrm{H} 2 \mathrm{KC}$ & $3.81 \pm 0.08^{\mathrm{b}}$ & $3.92 \pm 0.08^{\mathrm{b}}$ & $6.80 \pm 0.14^{\mathrm{b}}$ & $6.80 \pm 0.14^{\mathrm{b}}$ & $10.45 \pm 0.22^{b}$ & $12.03 \pm 0.11^{b}$ \\
\hline XTQ & $3.39 \pm 0.08^{c}$ & $3.80 \pm 0.09^{c}$ & $6.39 \pm 0.14^{\mathrm{c}}$ & $6.39 \pm 0.14^{\mathrm{d}}$ & $9.01 \pm 0.20^{\mathrm{d}}$ & $10.96 \pm 0.25^{\mathrm{d}}$ \\
\hline FPD & $4.21 \pm 0.16^{\mathrm{a}}$ & $4.71 \pm 0.18^{\mathrm{a}}$ & $7.51 \pm 0.29^{\mathrm{a}}$ & $7.51 \pm 0.29^{a}$ & $11.50 \pm 0.18^{\mathrm{a}}$ & $12.87 \pm 0.18^{\mathrm{a}}$ \\
\hline W2KA & $3.58 \pm 0.15^{c}$ & $3.50 \pm 0.15^{c}$ & $6.53 \pm 0.29^{c}$ & $6.53 \pm 0.29^{c}$ & $10.27 \pm 0.23^{b}$ & $11.59 \pm 0.24^{c}$ \\
\hline
\end{tabular}

Values expressed as mean duplicate and standard deviation value.

Mean value with the different superscript in the same column are significantly different $(\mathrm{p}<0.05)$ at $95 \%$ confidence interval.

$\mathrm{H} 2 \mathrm{KC}=\mathrm{Control}$ sample stored in the room temperature

$\mathrm{XTQ}=$ Control sample stored in the refrigerator

FPD $=$ Market sample stored in the room temperature

W2KA = Market sample stored in the refrigerator.

Table 2. Results for Acid Value.

\begin{tabular}{|c|c|c|c|c|c|c|}
\hline \multirow{2}{*}{ Sample } & Week 0 & Week 1 & Week 2 & Week 3 & Week 4 & Week 5 \\
\cline { 2 - 7 } & $\begin{array}{c}\text { Acid value } \\
\mathbf{m g} / \mathbf{g}\end{array}$ & $\begin{array}{c}\text { Acid value } \\
\mathbf{m g} / \mathbf{g}\end{array}$ & $\begin{array}{c}\text { Acid value } \\
\mathbf{m g} / \mathbf{g}\end{array}$ & $\begin{array}{c}\text { Acid value } \\
\mathbf{m g} / \mathbf{g}\end{array}$ & $\begin{array}{c}\text { Acid value } \\
\mathbf{m g} / \mathbf{g}\end{array}$ & $\begin{array}{c}\text { Acid value } \\
\mathbf{m g} / \mathbf{g}\end{array}$ \\
\hline H2KC & $9.94 \pm 0.55^{\mathrm{b}}$ & $11.02 \pm 0.61^{\mathrm{b}}$ & $11.98 \pm 0.66^{\mathrm{b}}$ & $12.70 \pm 0.70^{\mathrm{b}}$ & $20.01 \pm 1.10^{\mathrm{b}}$ & $22.05 \pm 1.21^{\mathrm{b}}$ \\
\hline XTQ & $5.79 \pm 0.17^{\mathrm{d}}$ & $7.01 \pm 0.20^{\mathrm{d}}$ & $7.62 \pm 0.22^{\mathrm{d}}$ & $8.16 \pm 0.24^{\mathrm{d}}$ & $12.42 \pm 0.14^{\mathrm{d}}$ & $14.79 \pm 0.43^{\mathrm{d}}$ \\
\hline FPD & $10.85 \pm 0.18^{\mathrm{a}}$ & $12.02 \pm 0.20^{\mathrm{a}}$ & $13.07 \pm 0.22^{\mathrm{a}}$ & $14.12 \pm 0.24^{\mathrm{a}}$ & $21.30 \pm 0.36^{\mathrm{a}}$ & $24.05 \pm 0.40^{\mathrm{a}}$ \\
\hline W2KA & $6.63 \pm 0.39^{\mathrm{c}}$ & $8.20 \pm 0.16^{\mathrm{c}}$ & $8.79 \pm 0.77^{\mathrm{c}}$ & $9.14 \pm 0.80^{\mathrm{c}}$ & $13.98 \pm 0.17^{\mathrm{c}}$ & $16.34 \pm 1.18^{\mathrm{c}}$ \\
\hline
\end{tabular}

Values expressed as mean duplicate and standard deviation value.

Mean value with the different superscript in the same column are significantly different $(p<0.05)$ at $95 \%$ confidence interval.

$\mathrm{H} 2 \mathrm{KC}=$ Control sample stored in the room temperature

$\mathrm{XTQ}=$ Control sample stored in the refrigerator

FPD $=$ Market sample stored in the room temperature

$\mathrm{W} 2 \mathrm{KA}=$ Market sample stored in the refrigerator. 
used. The findings agree with the report of Lin (1993) [20] that peroxide value in sunflower oil significantly $(\mathrm{p}<0.05)$ increased after 2 weeks of storage in the same condition. This study suggested that, peroxide value of chips are dependent mainly on the oil type used and indirectly depend on the storage conditions [10]. In week $0-3,(p<0.05)$ for taro chips stored under refrigeration temperature, peroxide value increased at a slower rate, this was probably due to the cold system which reduced the photo oxidative rate in taro chips [24].

\section{Acid Value and $\mathrm{pH}$}

Tables 2 and 3 are the results of Acid value and $\mathrm{pH}$ respectively. $\mathrm{pH}$ is a major factor that influences the growth of microorganism [4]. The result for $\mathrm{pH}$ obtained shows that the $\mathrm{pH}$ decrease little by little as the storage week progressed. And the $\mathrm{pH}$ range from week 0-5 was between 7.08-6.88 which shows that the food sample can still be consumed when stored at room and refrigerator temperature for $0-5$ weeks.

The lower the $\mathrm{pH}$, the higher the level of fatty acid released, the $\mathrm{pH}$ reduced in value with respect to storage time. The $\mathrm{pH}$ values obtained were similar to the findings of Falola et al., (2014) [13].

The increase in the acid value also showed the degree of hydrolytic rancidity which is due to the breakage of ester bond by reaction of lipase, the higher the acid value the higher the degree of hydrolytic rancidity that set in [8].

Off-flavour is a function of rancidity. Auto oxidation occurs during the drying and hardening of oil. The degree of off-flavour in taro chips is dependent on the degree of saturation of oil used in frying; concentration of antioxidant and storage conditions [6]. The highest acid value was observed in the taro chips that was purchased from the market and was low in the control sample. Rancidity increased gradually at storage week 0-2 but rapidly at week 3-5 at room temperature which could be as a result of build up of free radicals which reacted with oil by exposure to light [10].

Also the low level of off-flavour or rancidity in control sample could be as a result of high amount of oxidant and carotene that the oil contains, thus preventing significant oxidation in fried taro chips [29].

\section{Determination of Microbial Count}

In this study, there was an increase in the number of bacteria count as the storage period progressed (Table 4). The highest bacterial count of $7.4 \times 10(\mathrm{cfu} / \mathrm{ml})$ was noticed in the taro chips stored under room temperature. The bacteria were due to the unhygienic handling during processing of the chips or due to contamination from skin, mouth, nose of the handlers which can be introduced directly into food [25]. Ironically, most food handler do not practice good personal hygiene and do not follow good manufacturing practices, which could reduce the occurrence of such bacteria in foods $[9,18]$.

Result of this study showed that taro chips purchased from the market have more microbial growth compare to the one that was processed in the laboratory. The high growth may be due to some microorganisms on the surface of the skin, mouth, nose of the handler which can be introduced directly into the food by processors. Microorganisms could be introduced while coughing or sneezing during processing $[27,35]$.

Effective packaging of the sample that was processed in the laboratory might have played a contributory role in the low counts of microorganism recorded. This finding is similar to the findings of (Aguayo et al., 2003) [3]. Moisture content is an important shelf life determinant, the higher the level of moisture, the higher the rate of microbial spoilage of food products and the faster the breakdown of oils in stored product. The effectiveness of storage condition also plays a major role in the microbial growth on the chips [5].

Also, the low count in yeast and mould can be related to the proper frying process that the taro chip was subjected to which might have eliminated any microorganisms that would have caused high yeast and mould growth. Microorganisms are ubiquitous and are therefore found in air, soil, water, foods and on human. It is only when large number of microorganism is present that they become hazardous. Result obtained from microbiological assessment of the chips showed that most fell within the limit for satisfactory and acceptable microbiological quality as specified by Sago et al., (2003) [34].

\section{Colour}

Colour is of great importance [22]. Colour is the first quality parameter evaluated by consumers, and is critical in the acceptance of the product. Consumers tend to associate colour with flavour, safety, storage time, nutrition and level of satisfaction due to the fact that colour correlates well with physical, chemical and sensory evaluation of food quality.

A major factor that determines colour changes in fried food is browning reaction which is often affected by processing temperature, food or ingredient composition, water activity storage time [30].

In the table 5 below $(p<0.05)$ showed that there was significant difference between the samples. The $\mathrm{L}^{*}$ value was higher than $\mathrm{a}^{*}$ and $\mathrm{b}^{*}$ in all the samples that was stored in both room and refrigerator temperature but was more obvious in the control sample because of the species used i.e. Colocasia esculenta and there was no much difference in the value obtained. Some authors have reported that the lightness of chips increases during early stages of frying while it remains constants afterward [19]. The $\mathrm{a}^{*}$ value for the market sample was higher than the control sample. The high $a^{*}$ value obtained was due to browning reaction that takes place during frying [31].

Finally, the $\mathrm{b}^{*}$ value was higher in the control sample than in the market sample. The result suggest that the yellowness increases during frying and are in agreement with those obtained by other authors [19] and the colour was more preserved in the refrigerator due to the absence of light that might cause oxidation in the chips. However, no dark colour was observed in the store chip which suggested the absence of non-enzymatic browning in the stored in chips.

\section{Conclusions}


Table 3 Results for $\mathrm{pH}$ value.

\begin{tabular}{|c|c|c|c|c|c|c|}
\hline \multirow{2}{*}{ Sample } & Week 0 & Week 1 & Week 2 & Week 3 & Week 4 & Week 5 \\
\cline { 2 - 7 } & $\mathbf{p H}$ value & $\mathbf{p H ~ V a l u e ~}$ & $\mathbf{p H}$ value & $\mathbf{p H}$ value & $\mathbf{p H}$ value & pH value \\
\hline H2KC & 7.00 & 6.99 & 6.99 & 6.98 & 6.98 & 7.00 \\
\hline XTQ & 7.00 & 7.00 & 6.99 & 6.99 & 6.98 & 6.99 \\
\hline FPD & 7.02 & 7.01 & 7.00 & 7.00 & 7.00 & 6.91 \\
\hline W2KA & 7.02 & 7.0 & 7.00 & 7.00 & 7.01 & 6.89 \\
\hline
\end{tabular}

Value expressed as mean duplicate

$\mathrm{H} 2 \mathrm{KC}=$ Control sample stored in the room temperature

$\mathrm{XTQ}=$ Control sample stored in the refrigerator

FPD $=$ Market sample stored in the room temperature

$\mathrm{W} 2 \mathrm{KA}=$ Market sample stored in the refrigerator

Table 4. Bacterial, Yeast and Mould Count for Control and Market Samples of Cocoyam Chips.

\begin{tabular}{|c|c|c|c|c|c|c|c|c|c|c|c|c|}
\hline & \multicolumn{2}{|c|}{ Week0 } & \multicolumn{2}{c|}{ Week1 } & \multicolumn{2}{c|}{ Week2 } & \multicolumn{2}{c|}{ Week 3 } & \multicolumn{2}{c|}{ Week 4 } & \multicolumn{2}{c|}{ Week 5 } \\
\hline Sample & TVC & YMC & TVC & YMC & TVC & YMC & TVC & YMC & TVC & YMC & TVC & YMC \\
\hline H2KC & NG & NG & $0.9 \pm 0.00$ & $3.0 \pm 0.10$ & $1.5 \pm 0.00$ & $7.0 \pm 0.11$ & $3.5 \pm 0.00$ & $12.0 \pm 0.11$ & $4.2 \pm 0.00$ & $20.0 \pm 0.11$ & $5.6 \pm 0.00$ & $30.0 \pm 0.11$ \\
\hline XTQ & NG & NG & $0.5 \pm 0.00$ & NG & $1.8 \pm 0.00$ & $4.0 \pm 0.11$ & $2.8 \pm 0.00$ & $10.0 \pm 0.10$ & $3.6 \pm 0.00$ & $18.0 \pm 0.11$ & $4.8 \pm 0.00$ & $25.0 \pm 0.11$ \\
\hline FPD & NG & NG & $1.5 \pm 0.11$ & $6.0 \pm 0.11$ & $2.8 \pm 0.11$ & $13.0 \pm 0.11$ & $4.8 \pm 0.11$ & $19.0 \pm 0.00$ & $5.0 \pm 0.11$ & $38.0 \pm 0.00$ & $7.4 \pm 0.11$ & $38.0 \pm 0.11$ \\
\hline W2KA & NG & NG & $1.0 \pm 0.11$ & $4.0 \pm 0.11$ & $2.2 \pm 0.11$ & $9.0 \pm 0.11$ & $3.7 \pm 0.10$ & $15.0 \pm 0.10$ & $4.7 \pm 0.11$ & $23.0 \pm 0.11$ & $6.2 \pm .010$ & $32.0 \pm 0.11$ \\
\hline
\end{tabular}

Key: NG- No growth, TVC= Total viable count, $\mathrm{YMC}=$ Yeast and mould count, $\mathrm{H} 2 \mathrm{~K}=$ Control sample stored in room temperature, $\mathrm{XTQ}=\mathrm{Control}$ sample stored in refrigerator $\mathrm{FPD}=$ Market sample stored in room temperature, $\mathrm{W} 2 \mathrm{KA}=$ Market sample stored in refrigerator.

Table 5. Results for colour.

\begin{tabular}{|c|c|c|c|c|c|c|c|c|c|c|c|c|c|c|c|}
\hline \multirow{2}{*}{ Sample } & \multicolumn{3}{|c|}{ Wk 0} & \multicolumn{3}{|c|}{ Wk 1} & \multicolumn{3}{|c|}{ Wk 2} & \multicolumn{3}{|c|}{ Wk 3} & \multicolumn{3}{|c|}{ Wk 4} \\
\hline & $\mathrm{L}$ & A & b & L & $\mathrm{a}$ & b & L & A & b & L & $\mathrm{a}$ & b & L & $\mathrm{a}$ & b \\
\hline $\mathrm{H} 2 \mathrm{KC}$ & $63.57+0.06^{2}$ & $0.35+0.01^{d}$ & $23.90+0.01^{c}$ & $72.23+0.37^{b}$ & $6.05+0.06^{\mathrm{b}}$ & $34.58+0.94^{b}$ & $88.63+0.53^{b}$ & $18.72+1.75^{b}$ & $45.30+0.93^{2}$ & $96.63+0.53^{b}$ & $25.30+0.28^{b}$ & $20.11+0.01^{c}$ & $101.25+0.07^{b}$ & $30.60+0.57^{\mathrm{b}}$ & $22.13+0.04$ \\
\hline XTQ & $60.30+0.01^{c}$ & $0.55+0.11^{c}$ & $11.49+0.01^{\mathrm{b}}$ & $106.98+0.7^{a}$ & $2.33+0.09^{d}$ & $40.71+1.17^{a}$ & $110.28+1.17^{2}$ & $2.75+0.20^{d}$ & $43.09+0.29^{\mathrm{b}}$ & $120.11+0.0^{\mathrm{a}}$ & $3.51+0.01^{\mathrm{d}}$ & $45.15+0.07^{a}$ & $130.05+0.07^{a}$ & $4.05+0.07^{\mathrm{a}}$ & $5: 05+1.34^{a}$ \\
\hline FPD & $60.57+0.03^{b}$ & $5.93+0.01^{2}$ & $11.49+0.01^{\mathrm{b}}$ & $51.40+1.28^{d}$ & $2.75+0.20^{c}$ & $11.58+0.03^{c}$ & $54.20+0.04^{d}$ & $16.57+0.54^{\circ}$ & $15.34+0.17^{\mathrm{d}}$ & $65.11+0.11^{\mathrm{d}}$ & $20.55+0.64^{c}$ & $18.55+0.64^{d}$ & $70.11+0.1^{\mathrm{d}}$ & $29.11+0.01^{c}$ & $20.60+0.57^{d}$ \\
\hline WSA & $56.18+0.01^{\mathrm{b}}$ & $3.50+0.01^{2}$ & $12.44+0.01^{2}$ & $57.95+0.21^{b}$ & $20.22+0.34^{4}$ & $11.49+0.01^{\mathrm{d}}$ & $61.65+0.10^{c}$ & $20.55+1.95^{a}$ & $19.24+{ }^{`} 1.51^{c}$ & $72.20+0.03^{c}$ & $30.06+0.51^{2}$ & $28.76+0.35^{b}$ & $79.13+0.04^{4}$ & $40.18+0.11^{2}$ & $31.63+0.53^{b}$ \\
\hline
\end{tabular}

Values expressed as mean duplicate and standard deviation value.

Mean value with the different superscript in the same column are significantly different $(\mathrm{p}<0.05)$ at $95 \%$ confidence interval.

$\mathrm{H} 2 \mathrm{KC}=$ Control sample stored in the room temperature

$\mathrm{XTQ}=$ Control sample stored in the refrigerator

FPD $=$ Market sample stored in the room temperature

$\mathrm{W} 2 \mathrm{KA}=$ Market sample stored in the refrigerator

The market and control samples that were stored in the refrigeration temperature had low peroxide values, acid values, bacterial, yeast and mould counts compared to those stored at the room temperature. The low values in the above parameters were observed in the control samples that were processed in the food processing laboratory which might be due to the proper handling and good hygiene practice that was exhibited during the processing of the fried cocoyam chips.

The high peroxide and acid values of market samples were due to the type of oil used and re-used over a long period of time, low amount of antioxidants in the oil, reaction involving oxygen absorption and light penetration. The $\mathrm{pH}$ ranges of the fried cocoyam chips were within the limits of ready to eat food and showed that the chips could still be consumed when stored at room and refrigeration temperature.

Many people in Nigeria consume fried cocoyam chips on daily basis. It is a ready to eat food which is cheap and readily available. In conclusion, government and regulatory agencies should educate commercial producers on continuous re-use of frying oil and the need for good manufacturing practices to prevent recontamination of fried cocoyam chips.

\section{References}

[1]. Abaka-Gyenin AK, Norman JC. The effect of storage on fruit quality of water melons (Citrullus vulgaris Schad). Acta Horticulturae 53: IV Africa symposium on Horticultural crops. 2000

[2]. Aderolu AZ, Sogbesan OA. Evaluation and potential of cocoyam as carbohydrate source in catfish. Afr J Agri Res. 2010 Mar 18;5(6):453- 457.

[3]. Aguayo E, Allende A, Artes F. Keeping quality and safety minimally fresh processed melon. Eur Food Res Technol. 2003 Jun;216(6):494-499.

[4]. Akhigbemidu W, Musa A, Kuforiji O. Assessment of the microbial quality of noodles and the accompany seasonings. Nigerian Food J. 2015 Jun;33(1):48-53

[5]. Alam MS, Islam MR, Begum MF, Sarkar MA, Banu MS. Abundance of fungal flora in relation to moisture content and storage period in different types of poultry feeds ingredient. Pak J Biol Sci. 2001;4(10):1194-1197.

[6]. Amir HG, Monsen B, Mohammad AS. Antioxidants activity and total phenolic compound of pistachio (Pistachio vera) hull extract. Food Chemistry. 2005 Sep;92(3):521-525.

[7]. AOAC. Official methods of Analysis. 17th ed. Association of Official Agricultural Chemist, Washington, D.C. USA.

[8]. Arawande JO, Borokini BF. Comparison of antioxidative effect of methanol peel extract and but glared hydro utilize me on stability of crude peanut oil. Nigerian Food J. 2015;33(1): 35-38. 
[9]. Bukar A, Yushau M, Adiukwu EM. Incidence and Identification of potential pathogens on hand of some personnel in some small-scale food industries in Kano metropolis. Biol Environ Sci tropi J. 6:4.

[10]. Emmanuel-Ikpeme CA, Eneji CA, Easier U. Storage Stability and Sensory Evaluation of Taro chips Fried in Palm oil, Palm olein oil, Groundnut oil and Soyabean oil and their Blends. Pak J Nutr. 2007;6(6):570-575.

[11]. Esturk KO, Kayacier A, Sigh RK. Reduction of oil uptake in deep fried tortilla chips. Food Sci Technol Int. 2000;6:425-431.

[12]. Fagbohun ED, Abegunde OK, David OM. Nutritional and mycoflora changes during storage of plantain chips and the health implications. J Agri Biotechnol Sustain Dev. 2010 May;2(4):61-65.

[13]. Falola AO, Olatidoye OP, Adesala SO, Amusan M. Modifications and quality characteristics of cocoyam starch and its potential for chin-chin production. Pak J Nutrition. 2014 13(12): 768-773.

[14]. Hawrysh ZJ, Erin MK, Kim SS, Hardin RT. Quality and stability of potato chips fried in canola, partially hydrogenated canola, soybean and cottonseed oils. J Food Quality. 1996 Apr;19(2):107-120.

[15]. Hawrysh ZJ, Erin MK, Kim SS, Hardin RT. Sensory and chemical stability of tortilla chips fried in canola oil, corn oil, and partially hydrogenated soybean oil. J Am Oil Chem Soc. 1995 Oct;72(10):1123-1130.

[16]. Hindra F, Baik OD. Kinetics of quality changes during food frying. Crit Rev Food Sci Nutr. 46(3):239-258. PubMed PMID: 16527755.

[17]. Jia, HL, Ji QL, Xing SL, Zhang PH, Zhu GL, Wang XH. Chemical composition and antoxidant, antimicrobial activities of essential oils of Thymus marschalliamu Willi and Thymus Proximus Serg. J Food Sci. 2010 Feb;75(1):E59-E65. PubMed PMID: 20492167.

[18]. Kawo HA, Abdulmumin FN. Microbiological quality of pre-packaged sweet sold in Metropolitan Kano, Nigeria. Bayero J Pure Appl Sci Bajopas. 2009 Jun;2(1): 154-159.

[19]. Krokida MK, Oreopolou V, Marouli ZB, Marinos-Kouris D. Colour changes during deep fat frying. J Food Eng. 48(3): 219-225.

[20]. Lin HW. Flavour and Stability of potato Chips fried in canola, High oleic acid sunflower, sunflower and cotton seed oils. The university of Tennessee. 1993 Jan; 173.

[21]. Malcolmson LJ, Vaisey-Genser M, Przybylski R, Ryland D, Eskin NA, Armstrong L. Characterization of stored regular low-linolenic canola oils at different levels of consumer acceptance. J Am Oil Chem Soc. 1996 Sep;73(9):1153-1160.

[22]. Manque T, Penninex S, Kharoubi A. Image segmentation and bruise identification on potato using a kohonens self organizing map. J Food Sci. 2005 Sep;70(7):415-417.

[23]. Mathaus B. Use of palm oil for frying in comparison with other high-stability oils. Eur J Lipid Sci Technol. 2007 Apr;109(4):400-409.
[24]. Nawar WW. Lipid. In: Fennema OR, Editor. Food Chemistry. 3rd ed. New York: Marcel Dekker Inc. 1996;225-319.

[25]. Ochei KC, Obeagu EI, Amukwu VE, Mbajiuka CS. The bacteriological of fried ready-to-eat food sold in Enugu Metropolis, Nigeria. IOSR-JESTFT. 2014 Sep;8(9):81-92.

[26]. Ojinnaka MC, Akobundu EN, Iwe MO. Cocoyam Starch Modification: Effect on Functional, Sensory and Cookies Qualities. Pak J Nutr. 2009;8(5):558-567.

[27]. Okonko IO, Adejoye OD, Ogunnusi TA, Faboji EA, Shittu OB. Microbiological and Physiochemical analysis of different water samples used for domestic purposes in Abeokuta and Ojota, Lagos state, Nigeria. Afr J Biotechnol. 2008 Mar;7(5):617-621.

[28]. Onopikse OU, Wutoh JG, Ndazana X, Tambong JT, Mekoba MM, Sama AE, et al. Evaluation of Macabo cocoyam germplasm in Cameroon. In: Janick J, editor. Perspective on new crops and new uses. ASHS Press. 1999;339_ 396.

[29]. Pangloli P, Melton SL, Collin JL, Penfield MP, Saxton AM. Flavour and storage stability of potato chips, fried in cotton seed and sunflower oil and palm oleim/sunflower oil blends. J Food Sci. 2002 Jan;67(1):97-103.

[30]. Pedreschi F, Leon J, Mercy D, Morayo P. Implementation of a computer vision system to measure the colour of potato chips. J Food Sci. 2006 Dec;39(10):1092-1098.

[31]. Pedreschi F, Mery D, Mendoza F, Aguilera JM. Classification of potato chips using pattern recognition. J Food Sci. 2004 Aug;69(6):264-270.

[32]. Petukov I, Malcolmson LJ, Przybylski R., Armstrong L. Storage Stability of potato chips fried in genetically modified canola oils. J Am. Oil Chem Soc. 1999;76(8):889-896.

[33]. Raemakers R. Crop production in Tropical Africa. Directorate general for international cooperation, Belgium, 1539. 2001.

[34]. Sago SK, Little CL, Ward L, Gillespie IA, Mitchell TL. Microbiological study of ready-to-eat salad vegetables from retail establishment uncover a natural outbreak of salmonellosis. J Food Prot. 2003 Mar;66(3):403-409. PubMed PMID: 12636292.

[35]. Sobukola OP, Awonorin OS, Idowu AM, Bamiro OF. Microbial profile and critical control points during processing of "robo" snack from melon seed. Afr J Biotechnol. 2009 Mar;8(10):2385-2388.

[36]. Ukpabi UJ, Chijioke U, Mbanaso EN. Feasibility of producing acceptance carotene and energy rich taro chips with deep palm-oil frying in Nigeria. Pak J Nutr. 2013;12(9):811-814.

[37]. Warner K, Orr P, Parrott L, Glynn M. Effects of frying oil composition on potato chip stability. J Am. Oil Chem. Soc. 1994;71(10):1117-1121.

[38]. Zia-ur-Rehman, Salariya AM, Habib F. Antioxidant activity of ginger extract in sunflower oil. J Sci Food Agri. 2003 May 15;83(7): 624-629. 